\title{
A Latin-American Parents' Group Participates in their Children's Schooling: Parent Involvement Reconsidered
}

\author{
Judith K. Bernhard
}

Ryerson University

Marlinda Freire

University of Toronto

Veronica Pacini-Ketchabaw

Ryerson University

Virginia Villanueva

digital.library.ryerson.ca/object/372

Please Cite:

Bernhard, J. K., Freire, M., Pacini-Ketchabaw, V., \& Villanueva, V. (1998). A Latin American parents' group participates in their children's schooling: Parent involvement reconsidered. Canadian Ethnic Studies Journal 30(3), 77-98.

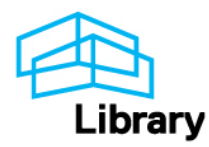




\title{
JUDITH K. BERNHARD, MARLINDA FREIRE, VERONICA PACINI-KETCHABAW AND VIRGINIA VILLANUEVA
}

\author{
A Latin-American Parents' Group Participates in Their \\ Children's Schooling: Parent Involvement Reconsidered
}

\section{ABSTRACT/RÉSUMÉ}

Ethnicity, with race, gender and class is a critical determinant in a number of social institutional interactions. This paper looks at a group of Latin American parents as they become more effective within a mainstream Canadian institution, their children's schools. Over an eight-month period, a group of eight to twelve Latino parents met monthly to discuss issues regarding their children's primary level schooling. The parents not only learned to assert their interests and collaborate with teachers, but they also became able to affirm the worth of their ethno-cultural differences. The parents began to take action and make their voices heard as they accomplished several goals in relation to the schools. This exploratory study focuses on how the parents' group helped its members understand their role in supporting their children's educational practices without devaluing their own cultural capital. Their adaptation may serve as a possible model for that required of a number of migrant groups in the coming millennium.

L'ethnie, avec la race, le sexe et la classe, est un facteur déterminant crucial dans un certain nombre d'interactions institutionnelles sociales. Cette communication examine un groupe de parents latinoaméricains pendant qu'ils deviennent plus actifs au sein d'une institution canadienne populaire, les écoles de leurs enfants. Sur une période de huit mois, un groupe de 8-12 parents latinoaméricains se sont réunis tous les mois dans le but de discuter de questions relatives ả l'éducation de leurs enfants au niveau élémentaire. Les parents ont non seulement appris à affirmer leurs intérêts et à collaborer avec les enseignants, mais aussi à être en mesure de faire valoir leurs différences ethno-culturelles. Les parents ont commencé à agir et à faire entendre leurs voix pendant qu'ils réalisaient plusieurs de leurs buts relativement aux écoles. Cette étude préliminaire s'est concentrée sur la façon dont le groupe de parents a aidé ses membres à comprendre leur rôle à soutenir les méthodes pédagogiques de leurs enfants sans dévaluer leurs propres ressources culturelles. Leur adaptation pourrait servir de modèle éventuel pour ce qui sera exigé des groupes migrants au cours du millénium qui vient.

When I go to meetings about the report card, I am not given many answers. I leave the same as I came. The teachers assume that you understand all this. You feel as though the teacher is saying there is nothing to discuss, especially if your child does not have serious problems, if your child is at grade level. They just give you the report card, assume you understood it, but don't give many opportunities to ask. So I leave as if 1 had understood what they said but in reality I did not understand. 
Mrs. Blanco ${ }^{1}$ in the above quotation is speaking to other Latin American parents in a group who meet regularly to discuss their children's problems in the educational system. Mrs. Blanco is a single mother of two, a nine-year-old girl and a three-yearold boy. She migrated from El Salvador six years ago where she was a secretary for a legal firm. Like many of these parents, she respects the efforts of the teachers yet feels left in the dark about problems her child may be having. The parents frequently said they were worried about their children's schooling, but apparently sensed little acknowledgment of their concerns by the teachers.

Sometimes I notice that my daughter is falling behind in school. She never has homework because the teacher says that she doesn't have any problems. He told me that I do not have to worry. I think he must know why he is saying that.

Although Mrs. Blanco, like many other parents, lacks information, she is willing to be favorably disposed toward the teacher. She does not blame the teacher, but herself. These parents' remarks show a specific set of problems this group has in making their voices heard in the educational system. They have often felt excluded from decision making that could improve their children's learning and they have looked for ways to be heard.

The goals of the present project were to explore the experiences of the designated Latin American families in the Canadian educational context and to determine, from their own perspective, the nature of the institutionally imposed disadvantages they face. As well, we wished to look at how the group involvement facilitated their becoming able to act effectively in their children's schools. It is to be noted that the larger research program has involved contacts with the main stakeholder groups in the Ontario system (Bernhard and Freire, 1996; Bernhard, Freire, and Lamphier, 1997; Bernhard, Freire, Torres, and Nirdosh, 1998).

In the present project, we report an experiment with an alternative form of parental participation in a small number of schools in the Toronto educational system. The conventional model set in place in Toronto involves a form of participation which on paper promotes equal opportunity, but in practice has numerous failings. Dehli (1987) analyzed policy and practice within the School Community Relations Department of the Toronto Board of Education.

By defining the constituency as 'parents' and constituting involvement in a formal meeting and textual mode-the taken-for-granted mode of bureaucratic practice - the very openings for participation confirm subordination, silence and 'apathy.' At the same time the structuring of parents' organization and representation is hierarchical. (p.234)

It is essential to critique proposed institutional models of parental involvement, specifically the constructions of parental roles and responsibilities. In accord with Dehli (1987) and Dei (personal communication, July 20, 1998), we argue that the nature of the supportive actions expected of parents cannot simply be assumed nor imposed on parents. The parents, within their specific context, deserve a primary role in determining the nature of their participation, defining their responsibilities, and establishing, collaboratively, how they and the teachers divide the labour of educating the child. Our parent group was intended to promote conscientization (Arés, 
Hernández, Alejandro, and Socarrás, 1997; Freire, 1972) and in general "to question the categories that orient practice and the forms which that practice takes" (Dehli, 1987: 238).

\section{Method}

\section{The Parents}

The group was open to Latin American fathers and mothers; these essentially constituted a sample of convenience. They had been recruited through word of mouth, television and newspaper features. The solicitation did not require or presume that the children were experiencing academic difficulty. Occasionally fathers attended some of the sessions. Although we refer to the group as a parents' group, the analysis is focused on the mothers who attended regularly. Support for children's schooling necessarily reflects the commonplace gender structure of such involvement. The families, as well as school officials, often assume that it is the mother's role to carry out routine tasks such as supporting the child or conferencing with the teachers; such support effectively being an extension of the woman's domestic work.

The parents who attended the group were from the following countries: Argentina, Chile, Peru, El Salvador, Uruguay, Venezuela, Nicaragua and Mexico. They resided in the Toronto area and had lived in Canada less than eleven years. Some of their children were born in Latin America, but most were born in Canada. The ages of the children attending school ranged from four to fifteen years old. In the home country, the parents had all completed high school, two had college degrees and one had attended university. However, none of the parents was able to continue their profession in Canada; they were working in factories, restaurants and in housekeeping. Table 1 summarizes backgrounds of the parents who participated regularly. We note here that the participants in this study differed from those in previous studies of Latinos in the United States since in the Toronto schools, Latin Americans were a very small minority. The children whose parents are described attended five different elementary schools in a large metropolitan area. None of the schools was in an upper class area and some were in the inner city.

\section{The Research Team}

The leader for the parents' group and the fourth author was a recent migrant from Mexico who had significant experience working with grass-roots women's groups in Latin America. She has a university education and is monolingual in Spanish. The third author is a recent migrant of Argentinian background who is carrying out doctoral studies at the University of Toronto. The second author completed her medical studies in Chile and moved to Canada where she completed post-graduate training in psychiatry. She is presently a school board Chief Psychiatrist. The first author lived in Chile until sixteen years of age and moved to Puerto Rico and then to Canada. Upon receiving her doctorate, she became a professor in the area of education.

\section{The Group Meetings}

Over an eight-month period, a group of eight to twelve Latin-American parents met once every month. They all had at least one child of primary school age. Parents attending the group were contacted through community associations and asked to 


\section{Table 1}

Backgrounds of the Latinas in the Group

\begin{tabular}{lcccc}
\hline Participant & $\begin{array}{c}\text { Country } \\
\text { of Origin }\end{array}$ & $\begin{array}{c}\text { Time } \\
\text { in Canada }\end{array}$ & $\begin{array}{c}\text { Age } \\
\text { of children }\end{array}$ & $\begin{array}{c}\text { Age of child } \\
\text { on arrival }\end{array}$ \\
\hline Mrs. Rodriguez & Nicaragua & $10 \mathrm{yrs}$ & $\begin{array}{c}\text { Child } \# 1-15 \\
\text { Child } \# 2-7\end{array}$ & $\begin{array}{c}6 \\
\text { Born in Canada }\end{array}$
\end{tabular}

Mrs. Romero

Peru

$10 \mathrm{yrs}$.

Child \#1 - 7

Born in Canada

Child \#2 - 1

Born in Canada

Mrs. Cabrera

Chile

8 yrs.

Child \#1 - 15

4

Child \#2 - 8

Born in Canada

Mrs. Perez

Uruguay

8 yrs.

Child \#1 - 10

7

Child \#2 - 13

5

Child \#3 - 7

Born in Canada

Mrs. Blanco

El Salvador

6 yrs.

Child \#1 - 9

3

Child $\# 2-3$

Born in Canada

Mrs. Palma

Mexico

7 yrs.

Child \#1 - 5

Born in Canada

Mrs. Ambrosia

Mexico

$1 \mathrm{yr}$.

Child \#1 - 6

5

Child \#2 - 9 mths

Born in Carrada

Mrs. Lorca

Chile

$10 \mathrm{yrs}$.

Child \#1 - 7

Born in Canada

Child \#2 - 5

Born in Canada

Mrs. Rosaldo

Argentina

6 yrs.

Child \#1 - 4

Born in Canada

Child \#2 - 2

Born in Canada

Mrs. Vargas

Uruguay

8 yrs.

Child \#1 - 14

7

Child \#2 - 13

5

Child $\# 3-7$

Born in Canada

Mrs. Torres

Nicaragua

9 yrs.

Child \#1 - 7

Born in Canada

Child \#2 - 4

Born in Canada

participate in this series of group sessions. The two-hour meetings were conducted in Spanish, and refreshments and child care were provided. The role of the facilitator, herself Latina, was to introduce each session and initiate the discussion by asking a neutral, open-ended question. On a rotating basis, there was a co-facilitator from among the group members who was in charge of providing for an orderly discussion. 
Each session was tape-recorded, transcribed and coded. The facilitator would summarize the topics discussed in previous sessions and ask the participants whether they wanted to elaborate on those topics or discuss other issues. In this way participants were able to comment in an ongoing way on interpretations of their previous statements.

The preliminary analysis was presented to the group of parents for verification. At a second stage, the identified themes were discussed informally with two experts in the field so as to validate them and corroborate their importance. From our transcribed audio tapes, we report on the parents' stories and accounts characterizing their encounters with the official discourses of schooling.

In elaborating our method it is important to note that we are working toward a systemic diagnosis of problems that simultaneously reflects the lived experience of the participants involved. We are not, at present, seeking to compare the experiences of Latin American immigrants with those of other backgrounds; commonalities must be the subject of rigorous comparative investigation. While our exploratory approach is intended to indicate linkages between ethnicity and particular difficulties, we are not proposing at the present time to demonstrate a simple causal thesis that the parents' ethnicity is the only or main factor to be looked at in the present situation. The relational nature of ethnicity is indicated below.

The goal of our analysis of parent-school interactions is not to assign blame; the good intentions of teachers and school administrators are, in our view, beyond dispute. We are examining the institutional processes of a particular context as lived by the participants and questioning outcomes that occur despite the good will of those involved. While we affirm that the educators are well-intentioned, we also recognize the validity of the sentiments of persons from immigrant backgrounds who may feel unfairly or poorly treated. Our aim is to show how these particular Latin American parents came to challenge labels of deficiency and act in resistance to the institutional procedures of mainstream schooling.

\section{Objectives and Research Questions}

The present paper is intended specifically to provide a "thick description" (Geertz, 1973) of how a group of parents supported each other, identified and dealt with a number of main issues in their struggle with a dominant Anglo institution. Their experiences with the larger society are illustrated by their difficulties with the educational system. Data were collected to address, in an exploratory manner, the following research questions and in particular to show how parents, through their group, learned how to address them more effectively: 1) How are school practices experienced by the Latin-American families? 2) How do the parents experience school and socially constructed roles for themselves? and 3) In what ways do the parents come to deal with institutional processes which disadvantage them as a migrant group with limited proficiency in the mainstream language?

Besides shedding light on minority/majority interaction in one educational setting, the paper describes a group action through which these Latin-American parents were able to better utilize their cultural capital and more effectively exercise power in society as illustrated in their encounters with the educational system. Their adaptation may serve as a possible model for that required of a number of newcomer groups in Canada in the coming millennium. 


\section{Theory and Context}

There is now an extensive literature on the positive impact of parental involvement on children's educational outcomes (Toronto Board of Education, 1991; Zigler, 1987). A number of recent studies have documented that meaningful teacherfamily relations are even more critical when parents and teachers come from different cultural and racial backgrounds because the two stakeholder groups are likely to differ in their approaches to child rearing (Holloway, Fuller, Rambaud, and Eggers-Piérola, 1998; Okagaki and Sternberg, 1993; Sjölund, 1973; West, Hausken, and Collins, 1993). Studies have demonstrated the positive impact of parent involvement on minority children's educational outcomes (e.g., Delgado-Gaitan, 1990; Diaz Soto, 1997; Trueba, 1984). The work of Alma Flor Ada (1988) has also provided evidence of the benefits of parents' direct participation on their children's reading acquisition. Because of this demonstrated correlation between home variables and children's success in school (e.g., Delgado-Gaitan. 1990; Ghazvini and Readdick, 1994; Goldenberg, 1993; Ramirez and Douglas, 1989), several Western countries have proposed policies and strategies to promote cooperation between parents and school staff (e.g., in Belgium, Verlot, 1995; in the U.S., Becher, 1985; Bright, Hidalgo, Siu, and Swap, 1994; in Canada, Drolet, 1994; Office des services de garde à l'enfance, 1994; Ontario Ministry of Education and Training, 1994; in Australia, Boston, 1995; in Portugal, Marques, 1995).

Yet parental involvement is often promoted too glibly. It is not a magic solution to all difficulties and indeed the concept itself is problematic. First, the ways in which parents participate may not be considered as the proper kind of involvement. A second and related point regards class bias. As Dorothy Smith (1987) noted, educational efforts to involve parents have often required a particular educational level; lacking that, the parents are found to be unable to give the prescribed forms of assistance in school. Third, the diagnosis of low or inadequate "parent involvement" is too easily used as a way of blaming parents for children's failure in school (K. Dehli, personal communication, August 20,1998). It is not surprising then, that there is mounting evidence that there are particular problems in relations between teachers and diverse parents. Parents in North America have been reported to feel coerced, not listened to, and not to have benefited from increased contact with the school (Bauch, 1992; Bernhard, Lefebvre, et al., 1998; Costas, 1991). Dei (1993a) has reported on efforts to involve Black/African-Canadian parents in the Toronto schools and identified systemic and racial barriers.

Our social-theoretical framework is first of all, structural: Systemic disadvantages are considered to be multiple, based on several dimensions, including class, race, gender and migrant status (Apple, 1992: $\mathrm{Ng}, 1993$ ). Power is seen as diffused in institutions and everyday practices of society (Bourdieu, 1986; Cannella, 1997; Corson, 1998; Looker, 1994). Following Ng (1993) we take gender, race, class and migrant status as constituted by relations and institutional social practices. In particular, ethnicity is not taken as an inherent group characteristic, but primarily as an ongoing ascription and construction by those constituting themselves as the dominant group(s). "Immigrant" is a construction of official discourse. The same arguments generally apply to "race" categories (Dei, 1993b).

Following Darder, Torres and Guttiérez (1997) we construe Latin-Americans as an ethnic group: the label Latino/Latina, here, is interchangeable with Latin-American. 
We are proposing that shared language, history, and culture are specific characteristics of this ethnic group, along with intra-group and extra-group perceptions. We are not proposing uniformity or same essence for these persons, and aspects of their heterogeneity are elaborated below.

In accord with Bourdieu (1986; see also Lareau, 1989), we construe 'cultural capital' as those dispositions (habitus) and capabilities that establish a person of a particular background and social stratum in a set of social relations; through such relationships, he or she produces and reproduces according to a socially constructed position. In our previous work with Latin-American families, we have found there is often a disparity of esteem between the cultural capital of the Latino families and that (implicitly) required by the school. Teachers' assessment of 'parental support' was found to be highly culture bound and focused on specific models of collaboration (Bernhard, Freire, Torres, and Nirdosh, 1998). Yet parents' actions, including the advice and guidance given to their children, are based on their own culturally bound view of the educational system. One may call this a situation of mismatch in skills and views, but in fact 'mismatch' is an ongoing aspect of social subordination. There is an undercutting of parents' abilities to positively affect their children's outcomes. We argue that there is some generality in Lareau's (1989) findings. The workingclass children receive a 'generic' educational experience; their families' cultural capital is nullified, constructed as ineffective by the educational system. Supporting such a general hypothesis, as applied to particular ethno-racial groups, are disturbing reports about school performance for some immigrant and ethnic groups (Bernhard and Freire, 1996; Bernhard, Freire, et al., 1998; Brown, 1994; Dei, 1993a).

The second framework on which we draw is cultural ecological theory. Anthropologists G. and L. Spindler have viewed schooling as "a mandated cultural process" (1990): Teachers transmit mainstream values and unwittingly undermine minority students' cultural identity. Students with endangered selves react in ways which contribute to their enduring marginalization (Trueba, 1993). Concepts proposed by other ecological theorists (Cummins, 1989, 1996; De Vos and Suarez-Orozco, 1990; Ogbu, 1987; Suarez-Orozco, 1989), help explain social outcomes for some minorities. Immigrant minorities, particularly those whose ethnicity differs from that of the mainstream frequently have poor school outcomes. With Ogbu, we assume that the common educational and social outcomes are conditioned by the historical experience of the ethnic or racial group as well as their present, socially constructed position of disadvantage. Cultural deficiency theories invert the cause and effect relationships (Barrera, 1997).

Anti-racist theory (e.g., Dei, 1993b) is foundational in our work, and we use a broad definition to reflect the special situation of Latin Americans with respect to the discrimination they face based on a number of factors. It is impossible to change the academic performance of children without understanding the context in which they live. The first set of contextual variables informing subordination is race, class and sex. The complex issue of the intersection of race and class has been explored by a number of writers (Anzaldúa, 1997; Barrera, 1997; Dei, 1993b; Diaz Soto, 1997; Macedo, 1997). As Barrera (1997) has pointed out, the middle classes of ethnic and minority groups still have a subordinate role in relation to the dominant Anglo upper and middle classes. A further pervasive dimension cutting across ethnic/racial divisions is the gender divide, and gender intersects with several ethno-racial 
categories (hooks, 1981; Moraga and Anzalduá, 1981; $\mathrm{Ng}$ and Ramirez, 1981). We would expect the complex structural situation to be reflected in personal experiences in a number of subtle ways (Smith, 1987).

In part, the frequent marginalization of newcomer parents is due to their isolation and the fact that there are no informal parent networks for sharing important information on school practices and dealing with such related problems. These difficulties are compounded by language barriers. Further, in the case of many immigrants, parents are afraid of school authorities so that even where a group is gathered, it may be important to convince them that they have little to fear and much to gain by being active. Social marginalization is a broad phenomenon with structural determinants already mentioned. Yet the above details indicate the nuances for immigrant groups as compared to other groups such as the working poor.

It is plausible then to seek to identify, analyze, and help overcome school difficulties by forming a special parents' group based on similar ethnic background, facilitated by native speakers of the language in question. This project represents an effort to learn parents' perspectives on those situations in which they may be labeled as passive or unconcerned. We see the parents' experiences as reflecting inequitable social structures but also as a basis for action to change problematic situations. This paper examines, therefore, how the parents' group helped the parents change their role in supporting their children's educational practices, without devaluing their own cultural capital, and be more effective in supporting their children's educational processes. On the basis of better understanding the situation of the parents, some suggestions are made at the end about what teachers need to learn and do about these issues. Measures to democratize the schools need to be addressed by all stakeholders; policy makers and administrators share with teachers the responsibility for the state of education.

\section{Background}

Canada is a nation of approximately 30 million people, of whom 17 percent are immigrants. Under the current five-year plan, Canada accepts approximately 235,000 immigrants yearly (Statistics Canada, 1998). The 1996 Census reveals that 3.2 million Canadians identify themselves as members of a visible minority. Compare this to 1.9 million in 1991 and 1.0 million in 1981. Toronto, Canada's largest city, is home to 1.4 million persons who identify themselves as part of a visible minority. Each year between 70,000 and 80,000 immigrants and refugees make Toronto their new home. They represent over half the total number of immigrants who settle in the province of Ontario, and about one third of those who come to Canada on an annual basis (Ornstein, 1997).

The diversity in the Canadian population is also illustrated in the variety of languages represented. According to Statistics Canada (1993), 32 percent of the total population of 27 million report a home language other than English or French. Canadian figures for those with Spanish as a mother tongue more than doubled from 70,000 in 1981 to 187,000 in 1996 (Statistics Canada, 1998). Although Latin Americans are spread out and are a very small minority in the Toronto schools, Latin American migrants represent one of the fastest growing groups in Canada and the 
United States (Coates, Jarratt, and Mahaffie, 1990). In 1991, approximately 56,000 people in the Greater Metro Toronto area identified Spanish as their first language, an increase of about 30,000 or 87 percent since 1981 (Statistics Canada, 1993). There is a scarcity of research evidence based on ethnic or language group in Canada but what is known is disquieting. A Toronto Board of Education survey (Brown, 1994) showed that Latin-American children, along with Black and African students, had disproportionately low academic achievement as reflected in assignment to basiclevel programs. Further, a Toronto high-school study (Drever, 1996) reported that Latin-American students become disengaged from school at a rapid pace (for a study of the marginalization of Latino students in the U.S. see Zanger, 1994). If these difficulties are not addressed, problems ensue, both for the educational system and for the children; because of the high rate of influx, the problems can be expected to worsen.

Although 'parent involvement' is the official school policy in Toronto, LatinAmerican parents are generally said not to be involved in the schools; teachers' assumption that parents understand how the educational system works can lead to serious problems (Bernhard and Freire, 1996; Bernhard, Lefebvre, Kilbride, Chud, and Lange, 1998; Blakely, 1983). Rather than faulting these mothers and fathers for "poor parenting skills" and ineffective efforts to assist their children's schooling, it is important to gain a deeper knowledge of how Latin-American parents can use parental power as effective participants in educational decision-making processes.

\section{Findings}

The parents at the beginning of the study were isolated and the existence of the group served as a way to bring them together. They learned to talk to teachers and learned about the many unspoken and unarticulated signs that teachers look for in 'effective parents.' In the process of coming together to discuss their children's education, these parents began to understand their position as constituted by the system. They saw beyond their individual experiences, began supporting one another, began to speak up, and took steps toward customizing their children's programs. The parents, along with forming a group, were undergoing a process of conscientization as described by Freire (1972). They were feeling themselves capable of making changes and were realizing their own possibilities in what they formerly perceived as a 'brick-wall' situation. Power relations became more transparent to them; as the situation became less opaque, they became more able to envision how the situation could be transformed through their actions. Findings are now summarized in four areas: Description of the group and the parents' encounters with the educational system; Experiencing institutional barriers and moving ahead; Problematic interactions: The issue of 'passivity'; and subordination and recognition of disadvantages.

\section{Description of the Group and Parents' Encounters with the Educational System}

Most of the parents came from societies in which teachers were seen as authority figures. Many of the parents began attending the group meetings to obtain information on what was happening in the classroom. Mrs. Rodriguez and her husband emigrated from Nicaragua ten years ago and began attending the group to support her two children, a fifteen-year-old son and a seven-year-old daughter. 
I come to these meetings to find out about my children's education. I want to know how the system works, about split grades, why they mix children of different ages, what is the difference between a public and a Catholic school. I have many questions and sometimes do not know where to go.

\section{Mrs. Blanco said,}

Although there are so many Hispanics here in Toronto, it was as if there were not many people who could be said to know [about the educational system]. Those of us who have met here have learned and this will help us to develop, we can use the educational system and confront it. But the ideal now would be to make this more accessible. It is good that we are here discussing our ideas but the issue is to find ways of getting this information to the rest of the community.

As the group gained a sense of cohesion, their interests changed to discussing issues of power and supporting each other. The parents made numerous comments on how they felt their views were being validated and how joining voices was a powerful experience. Mrs. Rodriguez was articulate in noting the positive effects the group had on the participants.

This is the first group I have participated in that has this dynamic. We have a chance to fully explore the issues. We are not many in numbers and we all have a chance to talk. This has helped me to become part of this group. We have listened to each other and have shared things that are very much ours. We have something in common. 1 think it is our race....

The effects of the parents' support group were twofold. Not only did the parents become aware that the teachers could be their allies, but by sharing with each other, they became able to affirm their differences rather than accept marginalization or be assigned the label of deficient in parental values or motivation. Mrs. Blanco was able to overcome her fear of the teacher and began seeing her as a potential ally.

The group helped me understand my daughter. It helped me see that $I$ had certain rights and that my rights are upheld. It helped me understand that the person who is teaching my daughter is not a superior being whom I cannot reach and cannot talk to. The teacher and $I$ both have the same agenda, my daughter's education.

Being able to support others in understanding their marginalization in the educational system was an additional outcome of the group meetings. Mrs. Rodriguez said:

This group has served as a way for me to help friends who have problems with their children at school. I tell them: 'Look, you can come here, or do this, or do that.' It gives them [my friends] more strength. This has helped me to communicate to others [parents], because there are so many people who do not know how to confront this. 
The friendships the parents developed were crucial in helping them move forward. Mrs. Blanco and Mrs. Rodriguez began to visit each other at home and to support each other in becoming more informed about the political context of the school.

We got together with Ester and went to a talk on politics at the university. It was the first time we participated in something like this, we went together. They were all Canadians ... and the topic was political. It was not very easy. Participation in this group gave us confidence to undertake new levels of activity.

\section{Experiencing Institutional Barriers and Moving Ahead}

The parents participating in the group gave several examples of how they felt uncomfortable and not welcome when they entered the schools. Mrs. Romero, a Peruvian mother of two children aged fourteen months and seven years, believed that the assignment of her older child to a split-grade class was due to some weakness in the child's performance. The institutional procedure for assigning grade levels and for communicating with the teachers were entirely opaque to Mrs. Romero. Although she was eager to find out more about her child's classroom progress, she felt difficulties in reaching the teacher:

In my son's school, parents do not go into the classroom. The teacher receives the children in the morning and they go into the classroom. I don't have opportunities to speak with the teacher. I would like to know why my boy is in a split-grade class, but I don't know if I should ask the teacher without it coming from her first. I cannot just say: "I want you to change him to a straight-grade class." She must know why she put him in that class. I would not want to have problems with her. But it worries me a great deal.

The teacher and parent appeared unable to communicate with each other, and the parent got the impression that the teacher had no time and that the parent could not affect the decision. The parent did not understand the reasoning behind the child's placement in this particular classroom, and the teacher was likely unaware that this parent had concerns about the child's placement.

As the group progressed, the parents began to interact with the school personnel, to assert themselves and to know their views would be heard. Mrs. Blanco:

My daughter was enthusiastic about taking a trip for three days, so I paid for the ticket. But then she told me she did not want to go because she was going to feel alone and she had never been away from home. The principal told me that my daughter still had to go because I had already paid. So I said to him: 'Excuse me, but I cannot do that. If my daughter does not feel good about going, I will not send her.' I was firm and they gave me the money back. The group gives one more assurance to do what we think is right with our children.

This mother now knew that her views have validity. She understood better how the system works and that her input could be heard. In the process of coming together, the parents validated themselves and the so-called deficiencies seemed to disappear. They found ways to overcome the barriers and penetrate the school walls: 
I decided I am going to start to get in the school and to bother teachers so much that they are going to listen to me. Now, I am there. And with all the parents there are, and if we all start to get into the school and make them listen to us, they will let us in. The other day, the teacher asked me to go to school to help children with their reading.

\section{Problematic Interactions: The Issue of 'Passivity'}

Mrs. Perez, Uruguayan mother of three, speaks English reasonably well and places a high value on her children's education. Yet she feels put off by the teacher.

I was worried about how he [my son] was doing in math because I know he needs to be pushed to do things sometimes. So I went to the school to find out. The teacher told me he did not need any special classes because there was someone in the class who was helping to get him up to the class level. So I was happy after what the teacher had told me. But now that he finished school, they sent me an entire book to work on for the summer because he was behind in math. She should have sent daily homework and not waited until the end. I am a little unhappy about that. It does not seem right. If I would have known, I would have insisted that they give me something earlier. But the teacher told me not to worry.

The experience of Mrs. Perez reflects her encounter with what can be characterized as an expert, institutional approach. The teacher had the role of the 'expert' who made all the decisions about what the child needed. Although the teacher no doubt felt open to talking to the parents, within the institutional processes the knowledge and concerns of the mother were, in practice, rendered marginal. Mrs. Perez did not feel she was in a position to make her views known to the teacher. She did not want to criticize a teacher because of her fear that it would have possible repercussions for her child. The result of such an impasse would probably be labeled 'parental passivity' or 'lack of concern.' In fact, she did not know what to do.

During our early meetings, the parents were frustrated at the lack of progress their children were making but felt their questions were not welcome. The parents had reacted passively since they primarily viewed the teachers as authority figures. They had initially held images of these figures as inaccessible.

The parents began to take action and make their voices heard as they accomplished a variety of goals in relation to school personnel. For example, Mrs. Romero talked about how she was empowered to continue the discussion with the school as she encountered resistance with regard to her requests to enroll her child in French Immersion.

I told the teacher that I wanted my child to go to the French program, and she said no because my son didn't know English well enough. But I told the teacher: What's the difference if English is not my son's first language? French is also going to be a new language for him. I don't understand what the problem is going to be.... So the teacher arranged a special meeting in which the principal, someone from the board, a psychologist, and a social worker were present. When I got to the meeting, I was so scared, but I still told them what I wanted, and finally they said okay. 
There were other ways in which parents pushed the school personnel to take appropriate action. Mrs. Cabrera related:

I had a problem with Juanito. A child was hitting him so I told the teacher twice. She did not do anything. I told her: 'Call the child's mother because I don't want anything to happen to my child.' Immediately she said, 'I will talk to the child.' And the child calmed down. She called the mother and everything. But if one doesn't get firm, forget it, they keep on bypassing you over and over again.

This mother's feeling of being bypassed is in fact an experience of subordination, of inability to have any influence on the educational processes in which her child is involved. Mrs. Rodriguez, in a similar situation, found she could assert herself:

Once, the secretary of the school called me to pick up my son because he had painted his face and was distracting the other children in the classroom. So she said that my son's behaviour was out of control and I had to pick him up immediately. She told me they did not know what else to do. When I heard this, it felt as if somebody had poured a bucket of cold water on my head [I felt shocked and ashamed]. I sat on the bed, took a deep breath and was shaking. I told her that I was not going to go to pick him up. I did not think the situation was so terrible.

In the quotation above, Mrs. Rodriguez perceived that her son was being judged according to mainstream standards and his behaviour was being negatively characterized. It would be a mistake to call this mother unconcerned or overly permissive. She simply had her own view of the kind of play children might be properly involved in. The school's assessment of the situation, in her view, was being forced on her and she found the courage to communicate that this was not acceptable. She clearly had become aware that her views had validity and that by taking a stand, the school would be moved to acknowledge her wishes.

These examples show hints of the underlying complexity of the interactions between Latin-American families and school personnel. While, in a sense, there was a 'lack of parental participation,' the social phenomenon is not properly construed as lack of interest or 'passivity' on the part of parents. Rather, one must understand these actions in terms of how parents understand the system and how teachers and other educators presently carry out institutionalized roles in dealing with all students, including newcomers.

\section{Subordination and Recognition of Disadvantages}

When discussing the difficulties they felt in getting school personnel to listen to them, the mothers found that gender represented an important factor in their relations with school personnel. The mothers experienced their best chances of being heard by the teacher when they were accompanied by their husband or another male.

I've had instances in which I've gone to the school with my husband to speak with the teacher and I noticed something, like there was more consideration because he was there. Once, [teachers] asked him for his opinion, asked him what he thought about the situation, and they even gave him options, something that did not happen when I was alone. When I go to meetings with my husband, the teacher always tends to speak to him rather than to both of us. 
The parents, in a majority of cases, did not construe their difficulties in terms of 'racial problems'; they did not see themselves as fitting into a black/white framework. Their conceptions of race were entirely in accord with the following standard definition found in the Oxford English Dictionary:

Race: One of the great divisions of mankind having certain physical peculiarities in common. [e.g.] ... there are five races, Caucasian, ... (Sadie, 1989).

In the quotation below, Mrs. Romero is talking about her difficulty in locating herself in a mainstream racial framework. She talks of colour but does not identify with black, white, or aboriginal groups.

I think we have to be very clear about our position in this society. We bring many disadvantages ... due to the colour of our skin and our language ... I think our children also have these disadvantages at school. One day my daughter and I passed by two Native Canadians. So my daughter asked if they were also from Peru because they look like us ... Many times it happens to us that people think we are indigenous Canadians when in reality we are Latinos [laughs as if incredulous].

Mrs. Romero's narrative reflects internalized conventional knowledge: She says, "We bring many disadvantages due to the colour of our skin and our language." Construing racism in rather narrow categories, she seeks to place herself outside of it. Mrs. Romero, despite her own mixed background in Peru, does not see herself as partly of indigenous roots and does not identify herself at all with the aboriginal peoples of North America. Yet, in the broad sense, racialization may involve a number of factors besides skin colour; in that sense, language differences become constructed as a marker for racial difference. We will analyze the notion of race more fully after considering the following comments of Mrs. Rodriguez.

Sometimes we see discrimination in very subtle ways. For example in children who are beginning to speak English. I have seen cases where the children are placed in basic-level classes although they are capable of more advanced classes. As parents, we know our children are capable but the teacher insists on the basic-level programs. That is where we can detect discrimination. How is it possible that if we know that the child is capable of working at the advanced level, the teacher insists that he not take the advanced level? So we have to fight and say my son can do this.

Seemingly at variance with their rejection of racial categories, many of the parents had a sense of Latin-American people as being a race. As Mrs. Cabrera, a Chilean mother of two children said:

My son's school has a mainly Portuguese, Hispanic and Italian population. The problem is that the majority of teachers and authorities are people who do not have a Latino background. So there is always favoritism for other races [razas].

Mrs. Cabrera used the term 'raza' to mean an ethno-cultural background, not simply with reference to colour. Such usage invokes somewhat older definitions of 
race involving a people with a common ancestry. Two more definitions found in the Oxford English Dictionary (Sadie, 1989) are as follows:

Race: A tribe, nation, or people regarded as of common stock [e.g.] 1600 Winne ... [refers to] the last Prince of Wales of the British race.

Race: A group of several tribes or peoples regarded as forming a distinct ethnical stock [e.g.] 1883 Green [speaking of] ... a heritage of the whole German race.

An anti-racist theory in the broad sense is compatible with this wide definition since, as noted earlier, dominant groups carry out racialization in terms of a number of dimensions including citizenship, language, manners, customs, and physical appearance. In short, we submit that the Latin-American parents of this group can appropriately be said to have been racialized despite their more narrow understanding of the concept of race discrimination. In fact, several parents of darker skin colour referred to experiencing racism in this narrow sense (based on skin colour).

Although not generally experiencing themselves as a racial group, as the group progressed the parents began to see their similarities, their common ancestry, and this awareness made a difference. Latin Americans are just coming to a group consciousness but based on our parents' reports there is no evidence that the school recognized the Latin-American families as being a particular group. Such lack of recognition is contrasted with the U.S. situation where Latino parents are clearly defined by educators as stakeholders.

The parents recognized that their marginalization was also related to their socioeconomic position, their class. As Mrs. Perez noted, the inability to buy namebrand and label clothing was a disadvantage that her daughter is experiencing:

My daughter is always worried about the clothes she wears to school, the brand name of her running shoes, and she lives weighted down by such things. Children have great pressures with regard to brand names. I try to give good values to my children saying that it is not important to have expensive or brand-name clothes. I would think that this is the teachers' job, but it isn't. We, parents, fight for giving children those values and to make children understand that we cannot spend that much money, but these things are not valued at school.

Mrs. Perez was aware of the strong consumerist ideology permeating the schools and affecting parents' interactions with their children. Their children were valued outside the home according to the market price of their belongings rather than for being warm and caring:

The important thing is that the child have an awareness of the value of money, the hardships we have in making a living.... The way it is at the school ... It is totally different from what we want to transmit to them ... Here identity [who you are] is measured in how much money you make.

There may have been possibilities of discussions between teachers and parents about a consumerist market place, but neither side apparently had considered such collaboration. Mrs. Perez also had an awareness of the disadvantage experienced by the Latino community: 
What happens is that we are a community that still has to work very hard. Other communities are economically better off than we are. They are also politically unified. So, those communities evidently participate and have power and are strong.

We wish to comment on these data as follows: The school Mrs. Perez's children attend is in a poor, immigrant neighbourhood. In this school, cultural capital involved wearing the right clothes. The school is unconsciously furthering the dominant values of consumerism. The habitus shared by many of the Latino parents, which involves avoidance of expensive and ostentatious clothing, deserves to be recognized. Where parents believe that a focus on brand-name clothing is wrong, school officials and teachers should acknowledge these values (e.g., have media courses, role models). The school is a contested site, but as minority parent groups come to assert themselves, it could assume the role of supporting parents by providing the tools to resist this type of enculturation (Lucas, Henze, and Donato, 1997; Portes, Clark, and Lopez, 1981).

When the dominant group defines what cultural capital is, cultural differences become 'deficits' according to standard measures. The teachers, regardless of their sentiments, are placed in a position of being unable to evaluate the knowledge of working-class and minority families. Again, according to institutional criteria, the family's desire for collaboration is not recognized. Teachers without the time for personal contacts with their students may become unintentional purveyors of a mainstream ethnocentric view. In such circumstances, families face almost insurmountable structural barriers to true collaboration and partnerships.

\section{Discussion}

Governments, ministries and school boards continue to call for parent partnerships (e.g., Drolet, 1994; Ontario Ministry of Education and Training, 1994). Yet our findings point to a number of difficulties in meaningful implementation of such collaboration and these are hardly surprising given the lack of communication between teachers and newcomer families.

In the examples above, we have illustrated the Latino parents' experiences as they deal with institutional impediments. We are not in a position at present to generalize from these experiences nor to prescribe universally applicable remedies. We argue, however, from our familiarity with the group and its culture, as well as from these and other stakeholders, that these voices have likely provided some valid indications of systemic problems. We have arrived, moreover, at a better understanding of the so-called 'non-participation' of these specific parents; their alleged passivity was an effect of the dominance of present school institutions which have placed the parents outside the decision-making system and devalued their assets and skills. An aspect of the parents' behaviour, however, was their resistance to institutional norms and processes set out by the educational system, and the group made such resistance more conscious. The experiences of the parents of the group demonstrate that the school system is capable of being influenced.

Passivity in parents has often been reported, especially with regard to workingclass and immigrant parents. There may be, as well, participation variables in all parents who deal with highly institutionalized schooling. Without denying variables 
connected with class and income, we propose that ethnicity is vital in understanding and attempting to resolve the difficulties described above in view of the multiplicative interaction between ethnicity, class and gender. Would a focus on social class be more enlightening in the present case? We argue that for most of the people in our sample, the institutional interactions would be less understandable had we focused primarily on income and social status. All parents were high-school educated; many had post-secondary education. In accord with the ethnocultural background of these parents, they viewed teachers principally as authority figures and initially held images of school personnel as inaccessible. The parents began to take action and made their voices heard as they accomplished a variety of goals in relation to their children's education. The examples presented show hints of the underlying complexity of the interactions between Latino families and the school personnel.

Although the present project was conducted at the primary level of education, it seems evident from the parents' perspective that certain patterns of behaviour had already been long established between the parents and the school system. Any longranging improvements of the educational system would require structures for collaboration among parents, and between parents and teachers. If done at an early stage, parent groups may remain cohesive and strong and provide input to primary and secondary schools.

The problem of establishing early and long-term relationships between parents and school personnel has been constructively addressed in California by the Parent Support Project (PSP, Lee and Seiderman, 1998). The details that follow can provide possible indications of useful steps that can be taken in the setting we studied. The PSP staff help the staff at child care centres and parents to work together and set up programs for the benefit of the entire team. There are specific provisions of support to parents in job training, income-tax preparation and sick child care options. Evaluations of PSP indicate significant reductions in parental stress levels (Stein, 1988), increases in parental attendance and resource availability at the child care centres (Haggard, 1991), and increased feeling of empowerment to address challenges (Lee, 1995). Yet each parent participation program encounters both specific and generic difficulties. There are no simple recipes. For an analysis and friendly critique of another parent support program in an Appalachian region, see Cochran (1993).

The question of teachers' understanding and practice needs to be addressed for this approach to work. What explains the absence of interactions in which parents and teachers meet and listen to each other's concerns? The educational system assumes a standard model of interaction: teachers set up teacher-parent meetings and conferences with one-way agendas; the process renders many parents powerless (Dehli, 1994; MacLure and Walker, 1998). Parents are expected to come and receive what is offered, or, alternatively, make polished presentations backed by expert assessments lobbying for services required by their children. Where there are few or inadequate mechanisms for involving parents and eliciting their input, the type of difficulty we have described is likely to occur, particularly in diverse settings. Parents will not be able to effect changes unless structures are changed to enable two-way interactions for both sides to listen and talk, for parents to have some power to ensure their ideas are implemented. One key component of establishing a collaborative model is for teachers to develop an understanding of families' cultures and concerns, 
and to obtain practical experience in working with parents (Bernhard, GonzalezMena, et al., 1998; Gonzalez-Mena, 1997; Moll, Amanti, Neff, and Gonzalez, 1992). Further, teachers require the support of administrators and policy makers.

Teachers can play a critical role in devising, or facilitating, new arrangements. We present here an experiment in an alternative form of parental participation that acknowledges the particular historical context in which the families live and bases itself in parents' understanding of mainstream institutional processes. The project, in sum, involved the Latino parents as conscious, active participants in a liberating pedagogy.

\section{ACKNOWLEDGEMENT}

Funding for the project described has been generously provided by the Centre for Excellence in Research on Immigration and Settlement, Social Sciences and Humanities Research Council of Canada, and by Ryerson Polytechnic University. The authors wish to thank all the families for their participation in the study. The project benefited from the participation of our colleagues from the Spanish-Speaking Parents' Liaison Committee, the Parents' Committee of the International Languages Program, and the Spanish Teachers' Committee of the Toronto Board of Education. We gratefully acknowledge the support of Akua Benjamin and the staff at the Davenport-Perth Community Centre. We also wish to thank Maria Teresa Wilson, Neri Espinoza, Fidelia Torres, Carlos Torchia, Patricio and Luz Bascuñan for their support in organizing the parent group. Regarding analysis, we are grateful for the helpful comments of our colleagues George Dei, Jim Lisa Lee, Jim Cummins, Costanza Eggers-Piérola, Kenise Murphy Kilbride, Arlene Stairs, Kari Dehli, David Corson, Gloria Roberts Fiati, June Pollard, and Harold White. Correspondence concerning this article should be addressed to the first author, Dr. Judith Bernhard at Ryerson Polytechnic University, 350 Victoria Street, Toronto, Ontario, Canada, M5B 2K3.

\section{NOTES}

1. All names have been changed to protect confidentiality.

\section{REFERENCES}

Ada, A.F. (1988). The Pajaro Valley experience: Working with Spanish-speaking parents to develop children's use of reading and writing skills through the use of children's literature. In T. Skutnabb-Kangas and J. Cummins (Eds.), Minority education: From shame to struggle (pp. 223-238). Philadelphia, PA: Multilingual Matters.

Anzaldúa, G. (1997). Movimientos de rebeldía y las culturas que traicionan. In A. Darder, R. Torres, and H. Gutiérrez (Eds.), Latinos and education: A critical reader (pp. 259265). New York: Routledge.

Apple, M. (1992). The text and cultural politics. Educational Researcher, 21(7), 4-11.

Arés, P., Hernández, C.N., Alejandro, M., and Socarrás, E. (1997). El trabajo grupal: Colección educación popular de Cuba. Havana, Cuba: Editorial Caminos.

Barrera, M. (1997). A theory of racial inequality. In A. Darder, R. Torres, and H. Gutiérrez (Eds.), Latinos and education: A critical reader (pp. 3-44). New York, NY: Routledge. 
Bauch, P.A. (April 1992). Toward an ecological perspective on school choice. Paper presented at the annual meeting of the American Educational Research Association, San Francisco, CA. (ERIC Document Reproduction Service No. ED 346 595)

Becher, R.M. (1985). Parent involvement: A review of research and principles of successful practice. In L. G. Katz (Ed.). Current topics in early childhood education, Norwood, NJ: Ablex.

Bernhard. J.K., and Freire, M. (1996). Latino refugee children in child care: A study of parents and caregivers. Canadian Journal of Research in Early Childhood Education, 5(1), 59-71.

Bernhard, J.K., Freire, M., Torres, F., and Nirdosh, S. (1998). Latin-Americans in a Canadian primary school: Perspectives of parents, teachers, and children on cultural identity and academic achievement. Journal of Regional Studies, 19(3), 217-236.

Bernhard, J.K., Freire, M., and Lamphier, M. (1997, June). Methods of field work with refugee population: The experiences of Latin-American children in the Canadian educational system. Paper presented at the International Conference on Multicultural/Minority Groups, Jerusalem, Israel.

Bernhard, J.K., Freire, M., Torres, F., and Nirdosh, S. (1997, November). Norms for good parenting as sociocultural constructs: An ethnography of Latino refugee families' involvement in a Canadian metropolitan primary school. Paper presented at the Canadian Ethnic Studies Association Conference, Montreal, QC.

Bernhard, J.K., Gonzalez-Mena, J., Chang, H.N., O'Loughlin, M., Eggers-Pierola, C., Roberts Fiati, G., and Corson, P. (1998). Recognizing the centrality of cultural diversity and racial equity: Beginning a discussion and critical reflection on 'Developmentally Appropriate Practice.' Canadian Journal of Research in Early Childhood Education, 7(1), 81-90.

Bernhard, J.K., Lefebvre, M.L., Kilbride, K.M., Chud, G., and Lange, R. (1998). Troubled relationships in early childhoodeducation: Parent-teacher interactions in ethnoculturally diverse settings. Early Education and Development, 9(1), 5-28.

Blakely, M.M. (1983). Southeast Asian refugee parents: An inquiry into home-school communication and understanding. Anthropology and Education Quarterly, 14, 43-68.

Boston, K. (1995). NSW Department of School Education Priorities. Sydney. Australia: New South Wales Department of School of Education.

Bourdieu, P. (1986). The forms of capital. In J. C. Richardson (Ed.), Handbook of theory and research in the sociology of education (pp, 241-257). New York, NY: Greenwood.

Bright, J., Hidalgo, N., Siu, S., and Swap, S. (1994, April). Home-school connections with parents from diverse backgrounds in kindergarten and first grade. Paper presented at the annual meeting of the American Educational Research Association, New Orleans, LA.

Brown, R.S. (1994). A follow-up of the Grade 9 cohort of 1987 secondary student survey participants. Toronto, ON: Toronto Board of Education.

Cannella, G.S. (1997). Deconstructing early childhood education: Social justice and revolution. New York, NY: Lang.

Coates, J., Jarratt, J., and Mahaffie, J. (1990). Hispanics are the largest fast-growing minority population in the United States. Future work, (pp. 34-46). San Francisco, CA: JosseyBass. 
Cochran, M. (1993). Parent empowerment and parent-teacher action research: A friendly critique. Equity and Choice, 10(1), 36-40.

Corson, D. (1998). Changing education for diversity. Philadelphia, PA: Open University Press.

Costas, M. (1991). Hispanic parental involvement. M.S. Practicum: Nova University. (ERIC Document Reproduction Service No. ED 339 462)

Cummins, J. (1989). Empowering minority students. Los Angeles, CA: National Association for Bilingual Education.

Cummins, J. (1996). Negotiating identities: Education for empowerment in a diverse society. Los Angeles, CA: National Association for Bilingual Education.

Darder, A., Torres, R., and Gutiérrez, H. (Eds.). (1997). Latinos and education: A critical reader. New York, NY: Routledge.

Dehli, K. (1987). 'Ethnic' 'parent' 'community': The proper channeling of education politics. In J. Young (Ed.), Breaking the mosaic: Ethnic identities in Canadian schooling (pp. 224-239). Toronto, ON: Garamond.

Dehli, K. (1994). Parent activism and school reform in Toronto. Toronto, ON: Department of Sociology in Education, Ontario Institute for Studies in Education.

Dei, G. (1993a). Narrative discourses of black/African-Canadian parents and the Canadian public school system. Canadian Ethnic Studies, 25(3), 45-65.

Dei, G. (1993b). The challenges of anti-racist education in Canada. Canadian Ethnic Studies, $25(2), 36-51$.

Delgado-Gaitan, C. (1990). Literacy for empowerment: The role of parents in children's education. London, UK: Falmer.

De Vos, G.A., and Suarez-Orozco, M. (1990). Status inequality. Newbury Park, CA: Sage.

Diaz Soto, L. (1997). Language, culture and power: Bilingual families and the struggle for quality education. Albany, NY: State University of New York Press.

Drever, N. (1996). Frustrated learners: An ethnographic study of Spanish-speaking students at an inner-city high school in Toronto. Unpublished master's thesis, University of Toronto, Toronto, ON.

Drolet, C. (1994). S'adapter a la diversité: Faits saillants d'une enquéte sur la diversité ethnoculturelle les services de garde en garderie et en milieu familial et dans les agences de la région de Montréal. Petit à petit, 12(6), 8-10.

Freire, P. (1972). Pedagogy of the oppressed. New York, NY: Continuum.

Geertz, C. (1973). The interpretation of cultures. New York, NY: Basic Books.

Ghazvini, A.S., and Readdick, C.A. (1994). Parent-caregiver communication and quality of care in diverse child care settings. Early Childhood Research Quarterly, 9, 207-222.

Goldenberg, C. (1993). The home-school connection in bilingual education. In B. Arias and U. Cassonava (Eds.), Bilingual education: Politics, practice, and research (pp. 225250). Chicago, IL: National Society for the Study of Education.

Gonzalez-Mena, J. (1997). Multicultural isstes in child care. Mountain View, CA: Mayfield.

Haggard, M. (1991). PSP training evaluation report. Unpublished manuscript. 
Holloway, S., Fuller, B., Rambaud, M., and Eggers-Piérola, C. (1998). Through my own eyes: Single mothers and the cultures of poverty. Cambridge, MA: Harvard University Press.

hooks, b. (1981). Teaching to transgress: Education as the practice of freedom. New York, NY: Routledge.

Larcau. A. (1989). Home advantage: Social class and parental intervention in elementary education. New York: Falmer.

Lee, D. (1995). An evaluation of six Parent Support Services programs in San Francisco. Unpublished manuscript.

Lee, L., and Seiderman, S. (1998). Families matter: The Parent Services Project. Boston, MA: Harvard Family Research Project.

Looker, D.E. (1994). Active capital: The impact of parents on youths' educational performance and plans. In L. Erwin and D. MacLennan (Eds.), Sociology of education in Canada (pp. 164-187). Toronto, ON: Copp Clark Longman.

Lucas, T., Henze, R., and Donato, R. (1997). Promoting the success of Latino language minority students: An exploratory study of six high schools. In A. Darder, R. Torres, and H. Gutiérrez (Eds.), Latinos and éducation: A critical reader (pp. 373-397). New York, NY: Routledge.

Macedo, D. (1997). English only: The tongue-tying of America. In A. Darder, R. Torres, and H. Gutiérrez (Eds.), Latinos and education: A critical reader (pp. 269-278). New York, NY: Routledge.

MacLure, M., and Walker, B.M. (1998, April). Disenchanted evenings: The social organization of talk in parent teacher consultations in UK secondary schools. Paper presented at the annual meecting of the American Educational Research Association, San Diego, CA.

Marques, R. (1995, April). The impact of legislation on families in Portuguese schools. Paper presented at the annual meeting of the Centre on Families, Communities, Schools, and Children's Learning, San Francisco. CA.

Moll, L.C., Amanti, D., Neff, D., and Gonzalez, N. (1992). Funds of knowledge for teaching: Using a qualitative approach to connect homes and classrooms. Theory into Practice, $21(2), 132-141$.

Moraga, C., and Anzaldúa, G. (1981). This bridge called my back: Writings by women of color. Watertown, MA: Persephone.

$\mathrm{Ng}$. R. (1993). Racism, sexism, and nation building in Canada. In C. McCarthy and W. Crichlow (Eds.), Race, identity and representation in education (pp. 50-59). New York, NY: Routledge.

Ng, R., and Ramirez, J. (1981). Immigrant housewives in Canada. Toronto, ON: Immigrant Women's Centre.

Office des services de garde ál'enfance. (1994). Enquete sur la diversité ethnoculturelle dans les services de garde garderie ét en milieu familial, et dans les agences de la région de Montréal. Montréal: Author, Direction des communications de la recherche et du développement, Gouvernment du Québec.

Ogbu, J.U. (1987). Variability in minority school performance: A problem in search of an explanation. Anthropology and Education Quarterly, 18, 312-334.

Okagaki, L., and Sternberg, R.J. (1993). Parental beliefs and children's school performance. Child Development, 64, 36-56. 
Ontario Ministry of Education and Training. (1994). For the love of learning: Report of the Royal Commission on Learning. Toronto: Queen's Printer for Ontario.

Ornstein, M.(1997, March), Ethno-racial inequality in Metropolitan Toronto: Analysis of the 1991 census. Paper presented at the Urban Forum on Immigration and Refugee Issues, Toronto, ON.

Portes, A., Clark, J.M., and Lopez, M.M. (1981). Six years later: A profile of the process of incorporation of Cuban exiles in the U.S. Cuban Studies, 11 (July), 1-24.

Ramirez, J.D., and Douglas, D. (1989). Language minority parents and the school: Can home-school partnerships increase student access? (ERIC Document Reproduction Service No. ED 349 349)

Sadie, S. (Ed.). (1989). Oxford English Dictionary (2 ${ }^{\text {od }}$ ed., Vol. 13). Oxford, UK: Oxford University Press.

Sjölund, A. (1973). Day care institutions and children's development. Lexington, MA: Heath.

Smith, D. (1987). Women's work as mothers. In R. Miliband (Ed.), Socialist register. London, UK: Lawrence and Weinhart.

Spindler, G., and Spindler, L. (1990). The American cultural dialogue and is transmission. London, UK: Falmer.

Statistics Canada. (1993). Mother tongue: The nation. Ottawa, ON: Supply/Services Canada.

Statistics Canada (1998). Daily. Ottawa: Supply/Services Canada.

Stein, A.R. (1988). The Parent Service Project evaluation. Unpublished manuscript.

Suarez-Orozco, M.M. (1989). Central American refugees and US high schools: A psychosocial study of motivation and achievement. Stanford, CA: Stanford University Press.

Toronto Board of Education. (1991). Final report of the work group on parental involvement. Toronto, ON: Author.

Trueba, H. (1984). The forms, functions, and values of literacy. Journal of the National Association for Bilingual Education, 9, 21-38.

Trueba, H. (1993). Cultural diversity and conflict: The role of educational anthropology in healing multicultural America. In P. Phelan and A. L. Davidson (Eds.), Renegotiating cultural diversity in American schools (pp. 195-215). New York: Teachers College Press.

Verlot, M. (April 1995). School policy improvement and the connection with the local community: The Flemish experience. Paper presented at the annual meeting of the Center on Families, Communities, Schools, and Children's Learning, San Francisco, CA.

West, J., Hausken, E.G., and Collins, M. (1993). Readiness for kindergarten: Parent and teacher beliefs (National Centre for Education Statistics Report No. 93-257). Washington, DC: U.S. Department of Education, Office of Educational Research and Improvement.

Zanger, V.V. (1994). "Not joined in": The social context of English literacy development for Hispanic youth. In B. M. Ferdman, R. Weber, and A. G. Ramirez (Eds.), Literacy across languages and cultures (pp. 171-198). Albany, NY: State University of New York Press.

Zigler, S. (1987). The effects of parent involvement on children's achievement: The significance of home/school links. Toronto, ON: Toronto Board of Education. 


\section{Contributors/Collaborateurs}

Sharon McIrvin Abu-Laban

Yasmeen Abu-Laban

Gurcharn S. Basran

Judith Bernhard

Marlinda Freire is Professor of Sociology at the University of Alberta. She specializes in the study of families, gender and aging. Her research and scholarly publications focus on aging and intergenerational relations, gender and family adaptation and the integration of diasporic youth and women into Canadian society, with a focus on Arab and Muslim immigrants. She has published in Canadian and international journals and anthologies and is coeditor of The Arab World: Dynamics of Development and Muslim Families in North America.

is Assistant Professor in the Department of Political Science at the University of Alberta. Her research interests centre on the Canadian and comparative dimensions of immigration, gender, race/ethnicity and political representation, nationalism and globalization, and citizenship theory. Her publications include articles in Canadian Public Policy, The Canadian Review of American Studies, and chapters in several edited collections.

has taught in the Department of Sociology. University of Saskatchewan since 1965 . He is the co-author of three books and has published articles in national and international sociological journals in the areas of race and ethnic relations, agricultural sociology, and sociology of development. He is Professor and former Chair of the Department of Sociology and served as an Assistant Dean in the College of Arts and Science.

has addressed the needs of immigrant and refugee children and families through her work with young children, their families and teachers since completing her Ph.D. from the University of Toronto. Dr. Bernhard teaches child development at Ryerson Polytechnic University and has a particular interest in infants and toddlers in various contexts. Her focus is on pluralistic models that honour the role of culture in determining optimal caregiving practices.

is a psychiatrist with a background in paediatrics who arrived in Canada in 1974 from her native Chile. Her primary areas of expertise are immigrants and refugees, second language acquisition, and effects of poverty on mental health. Dr. Freire is an Assistant Professot in the Faculty of Medicine, Department of Psychiatry, University of Toronto. She is also a staff psychiatrist at the Hospital for Sick Children and provides Psychiatric Services at the Toronto School District Board. 
Joseph Garcea

Gustave Goldmann

Hugh Grant

Peter S. Li

Ron Oertel

Veronica Pacini-Ketchabaw

Dwaine Plaza teaches courses in public administration and public policy analysis in the Department of Political Studies at the University of Saskatchewan. His major area of interest in the field of immigration is federal-provincial relations. In addition to an indepth analysis of the phenomenon of asymmetrical federalism in the field of immigration, he has examined the Immigration Clauses in the Meech Lake and Charlottetown accords, and is currently examining the federal government's Settlement Renewal Initiative.

is a social demographer and senior researcher with Statistics Canada. He has published numerous articles and research papers on topics dealing with ethnic groups in Canada, Aboriginal demography, the adaptation of immigrants and the history and evolution of collecting socio-demographic data on large populations in Canada. He is one of four coauthors of a book on the demography of the Aboriginal people of Canada. He is also responsible for the publication of a series of major census monographs on socio-demographic and economic issues that are germane to the development of Canadian society into the next millennium.

is Associate Professor, Department of Economics, University of Winnipeg and a researcher with the Prairie Research Centre of Excellence on Immigrant and Integration.

is Professor of Sociology at the University of Saskatchewan, and Chair of the Economic Domain at the Prairie Centre of Excellence for Research on Immigration and Integration. His recent books include The Making of Post-War Canada (1996) and The Chinese in Canada, 2nd edition (1998); another edited book, Race and Ethric Relations in Canada, 2nd edition, is forthcoming in 1999.

is a graduate student in the Department of Economics, Queen's University.

is a native of Argentina and currently teaches on a part-time basis and is involved in several research projects at Ryerson Polytechnic University. She is also completing her doctoral studies at OISE/UT. Her areas of interest include social relations of knowledge and their dynamics in regard to educational issues confronting the Latin-American community in Canada.

is an Assistant Professor in the Sociology Department at Oregon State University. He completed his Doctorate at York University in 1996. His research interests are on the settlement and acculturation issues facing second generation Caribbeans in the 